\title{
CIGS nanostructure: preparation and study using liquid phase method
}

\author{
P. Jakhmola ${ }^{1,2} \cdot$ P. K. Jha ${ }^{1,2} \cdot$ S. P. Bhatnagar ${ }^{1,2}$
}

Received: 27 March 2015/Accepted: 30 May 2015/Published online: 10 July 2015

(c) The Author(s) 2015. This article is published with open access at Springerlink.com

\begin{abstract}
Present study is motivated by interesting attainment obtained for copper indium gallium diselenide compound as a light absorbing material for thin-film solar cell. Formation of copper indium gallium diselenide nanostructures via solvothermal method using starting precursors of copper, indium, gallium salts, and selenium powder is represented. Preparation is done by varying $x(0.1$ and 0.3$)$ in $\mathrm{CuIn}_{1-x} \mathrm{Ga}_{x} \mathrm{Se}_{2}$ compound at a constant temperature and using ethanolamine as a solvent. Characterization of nanostructures is done using powder X-ray diffraction, scanning electron microscopy, dynamic light scattering, Fourier transform infrared spectroscopy, and UV-Vis spectroscopy. It is found that grown chalcopyrite structure at different $x$, possess agglomeration in nanostructures. Results indicate that presence of $10 \%$ gallium in copper indium gallium diselenide compound leads to the single-phase growth, prepare at the temperature of $190{ }^{\circ} \mathrm{C}$ for $19 \mathrm{~h}$.
\end{abstract}

Keywords Copper indium gallium diselenide . Characterization $\cdot$ Nanostructures

\section{Introduction}

Among the group I-III- $-\mathrm{VI}_{2}$ semiconductor material, copper indium gallium (di) selenide is reported the highest efficiency of $20 \%$ as a solar cell device (Jackson et al.

P. Jakhmola

priya198508@gmail.com

1 Department of Physics, Maharaja Krishnakumar Sinhji Bhavnagar University, Bhavnagar 364001, India

2 Department of Physics, Maharaja Sayajirao University of Baroda, Vadodara 390002, India
2011). Numerous processes have been reported by many investigators for the synthesis of copper indium gallium diselenide (CIGS) nanostructures like mechanochemical (Rehani et al. 2013), colloidal route (Tang et al. 2008; Kim et al. 2005), green synthesis (Juhaiman et al. 2010), precipitation (Panthani et al. 2008), micro-wave synthesis (Bensebaa et al. 2010), mechanical alloying (Vidhya et al. 2011), etc. A very few reports had been perceived by solution-based techniques for the successful synthesis of CIGS nanoparticles in which reaction time, temperature, reagents, solvent, variation of Ga content, and optimal process are used for synthesis of CIGS nanostructures (Caballero et al. 2009; Repins et al. 2008; Bremeud et al. 2007). Main approaches to synthesize nanoparticles are categorized in top-down (source material is reduced from bulk size to nanoscale e.g. grinding) and bottom-up (piecing together of tiny systems to give rise grand systems) approaches. Vapor-phase (e.g., pyrolysis) and liquid-phase fabrication (e.g., solvothermal, sol-gel) are sub-categorized form of bottom-up approaches.

In present work, single-phase $\mathrm{Cu}\left(\mathrm{In}_{1-x} \mathrm{Ga}_{x}\right) \mathrm{Se}_{2}$ nanostructures have been synthesized via solvothermal approach by using ethanolamine as a solvent. To the best of our knowledge, there are very few reports on the synthesis of as-grown particles via mentioned technique. General concept for the liquid-phase fabrication process based on the solvothermal approach to demonstrate that the nanostructure formation is shown in Fig. 1.

\section{Experimental details}

Cupric chloride ( $>99.0 \%$ ) and selenium powder $(99.5 \%)$ have been purchased from S D fine, whereas Indium (III) chloride (99.99 \%) and Gallium (III) chloride (99.99\%) 


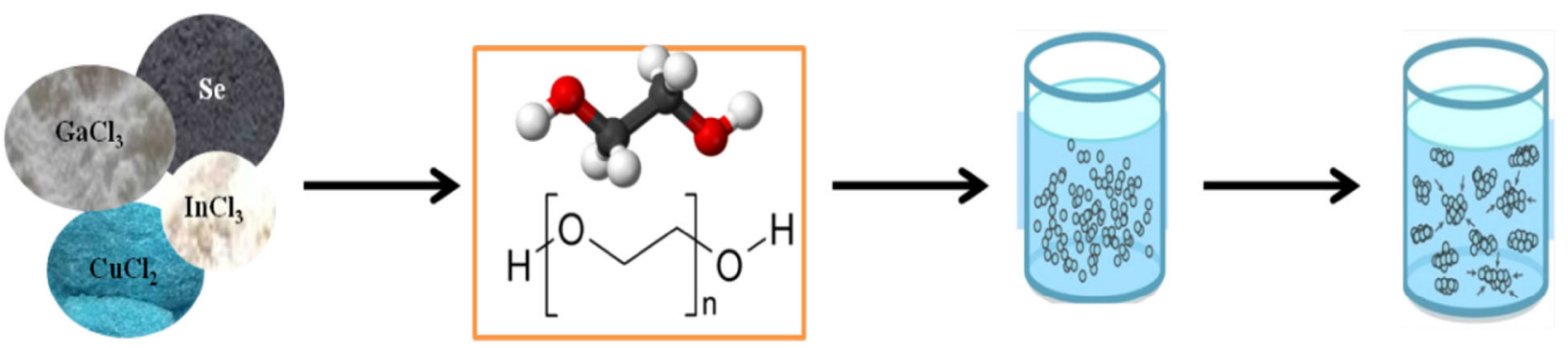

Precursors

Intermediate

Nucleation

Agglomeration

Fig. 1 General concept of the liquid-phase fabrication process based on the solvothermal approach

Fig. 2 The experimental procedure of CIGS nanoparticles growth via solvothermal process

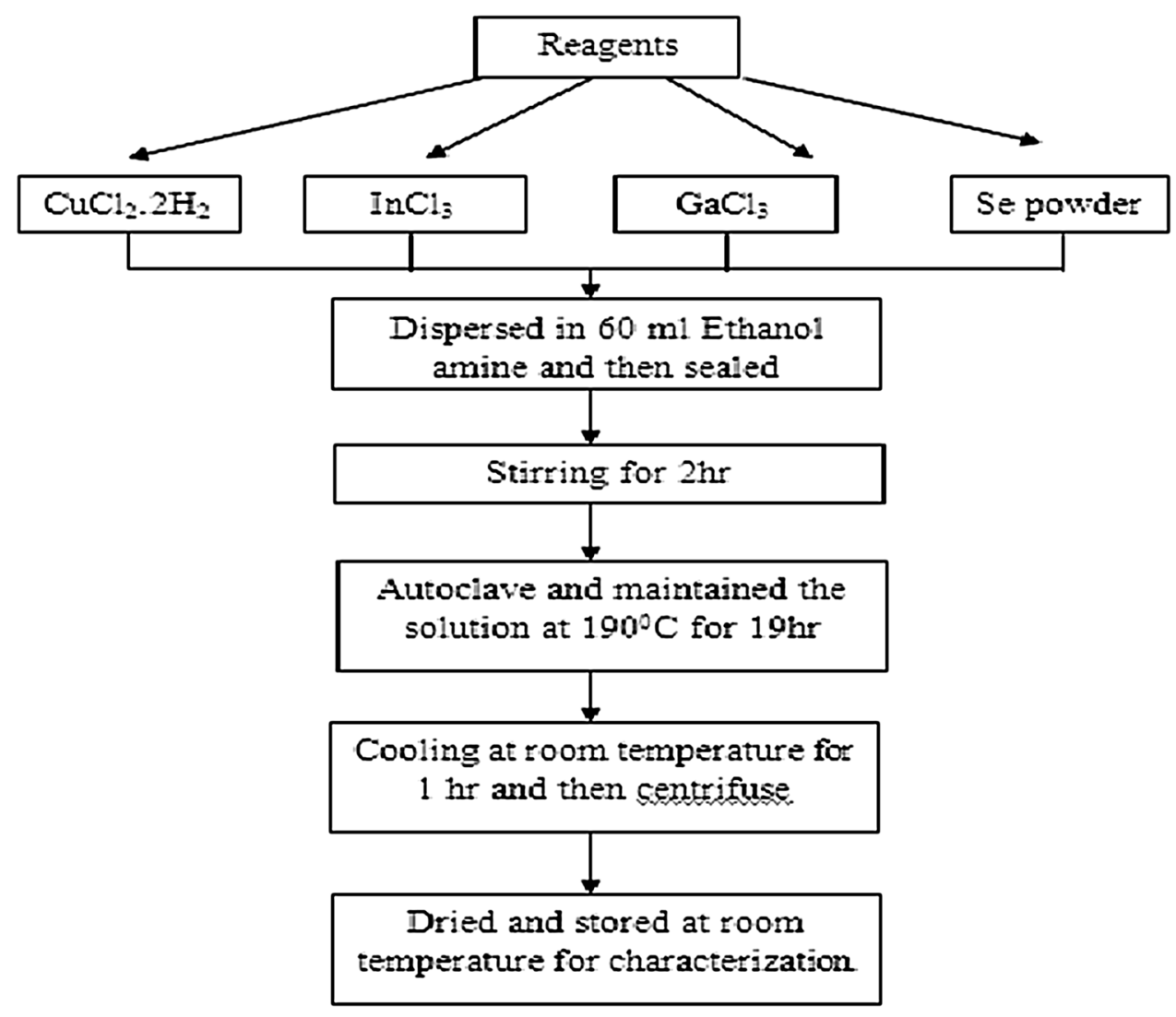

are from Sigma-Aldrich. Ethanolamine is purchased from Merck MSDS. All reagents are used as received without any further purification.

Figure 2 shows the experimental procedure of CIGS nanoparticles growth via solvothermal process. In a systematic experimental procedure, the synthesis of CIGS nanoparticles obtained by varying $x=0,0.1$, and 0.3 in $\mathrm{Cu}\left(\mathrm{In}_{1-x} \mathrm{Ga}_{x}\right) \mathrm{Se}_{2}$ nanostructure. Salts of dihydrate cupric chloride $(0.15 \mathrm{~g})$, Indium (III) chloride $(1-x)$, Gallium (III) chloride $(x)$, and Se $(0.300 \mathrm{~g})$ powder were loaded in a beaker containing $60 \mathrm{ml}$ of ethanolamine. The mixture is magnetic stirred for $2 \mathrm{~h}$ at room temperature measured $32{ }^{\circ} \mathrm{C}$, solution is turned into deep black from initial dark blue for both $x=0.1$ and 0.3 . The solution is autoclave and maintained at a temperature of $190{ }^{\circ} \mathrm{C}$ for $19 \mathrm{~h}$. The reaction is now allowed to cool at room temperature and finally black-colored particles are obtained. Methanol is added to as obtained product and then sonicate for $10 \mathrm{~min}$. Further the solution is centrifuge around $30 \mathrm{~min}$ and then rinse with distill water and acetone several times. Final obtained product is dried for further characterization. 
As-obtained product is first characterized by powder $\mathrm{X}$-ray diffraction Rigaku miniflex-II using $\mathrm{CuK} \alpha$ with $1.54060 \AA$ radiations in the $2 \theta$ range from $10^{\circ}$ to $90^{\circ}$ while the voltage and current are held at $40 \mathrm{kV}$ and $30 \mathrm{~mA}$, respectively. Surface morphology is studied by scanning electron microscopy using model LEO 1430 VP. Particle size is determined by dynamic light scattering using Malvern mastersizer 2000. Optical spectra are recorded using ELICO BL-198 in the range of $380-1100 \mathrm{~nm}$ and the energy band gap is also evaluated.

\section{Results and discussion}

The structural analysis of synthesized CIGS nanostructures has been determined using X-ray diffraction. Figure $3 \mathrm{a}-\mathrm{c}$ shows diffraction features of chalcopyrite structure of CIS and CIGS nanostructures. We can see that for diffraction pattern of $\mathrm{CuInSe}_{2}$ and $\mathrm{Cu}\left(\mathrm{In}_{0.9} \mathrm{Ga}_{0.1}\right) \mathrm{Se}_{2}$ synthesized at $190{ }^{\circ} \mathrm{C}$ for $19 \mathrm{~h}$, sharp and intense diffraction peaks are detected at diffraction angle $26.92^{\circ}, 44.47^{\circ}$, and $52.65^{\circ}$, shows chalcopyrite tetragonal structure by making match with the Joint Committee on Powder Diffraction Standards (JCPDS) card File No. 27-0159 (Alberts 2004). These peaks correspond to the preferred orientation plane of (112), (220/204), and (332/116), respectively. The less intense peaks observed at $71.06^{\circ}$ and $81.62^{\circ}$ correspond to the planes (332/316) and (424/228), respectively. For $\mathrm{Cu}\left(\mathrm{In}_{0.9} \mathrm{Ga}_{0.1}\right) \mathrm{Se}_{2}$ and $\mathrm{Cu}\left(\mathrm{In}_{0.7} \mathrm{Ga}_{0.3}\right) \mathrm{Se}_{2}$ compound, the presence of the peaks at (400/008) and (424/228) orientation results that Ga takes partly the place of indium in tetragonal phase and then result in tetragonal CIGS phase. It is clear that single phase is obtained when $x$ is taken 0.1 , revealing active participation of gallium in the formation of tetragonal chalcopyrite CIGS structure (see Fig. 3d). However, at $x=0.3$, we can observe few secondary phases or decrease in the quality of crystallinity and increase of defects in XRD pattern. It reveals that proper ratio of indium and gallium is necessary during synthesis. The FWHM of (112) peak increases with increasing $x$ given in Table 1 and hence decrease in grain size and should be ascribed to the lowest crystalline quality of the sample clearly outlined in Fig. 3c. The microstructure obtained by scanning electron microscopy is shown in Fig. 4a-c labeled as (a) $\mathrm{CuInSe}_{2}$ (without gallium), (b) $\mathrm{Cu}\left(\mathrm{In}_{0.9} \mathrm{Ga}_{0.1}\right) \mathrm{Se}_{2}$, and (c) $\mathrm{Cu}\left(\mathrm{In}_{0.7} \mathrm{Ga}_{0.3}\right) \mathrm{Se}_{2}$ nanostructures. We observe a remarkable difference in shape and size in samples without and with Ga. Dependence of gallium content on grain size interprets that the atomic radii of gallium are smaller than indium hence greater amount of gallium results in smaller grain size (Alberts 2004, 2009; Souilah et al. 2009; Zhang et al. 2009). Figure $4 \mathrm{~b}, \mathrm{c}$ shows soft agglomeration, also merging
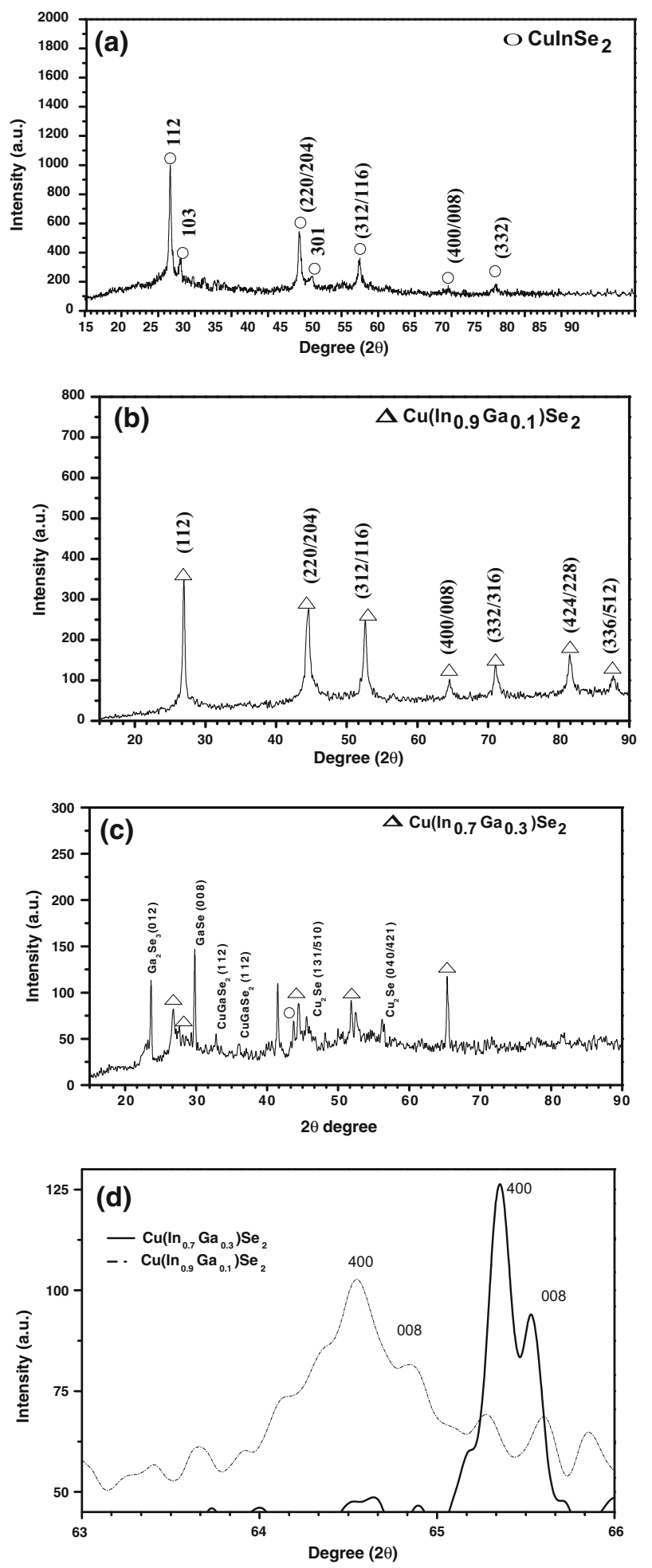

Fig. 3 X-ray diffraction of $\mathrm{CuInSe}{ }_{2}, \mathrm{Cu}\left(\mathrm{In}_{0.9} \mathrm{Ga}_{0.1}\right) \mathrm{Se}_{2}$, and $\mathrm{Cu}\left(\mathrm{In}_{0.7}\right.$ $\left.\mathrm{Ga}_{0.3}\right) \mathrm{Se}_{2}$ nanostructures grown via solvothermal approach at $190{ }^{\circ} \mathrm{C}$ for $19 \mathrm{~h}$

boundaries, non-spherical, and irregular formation of nanoparticles at $x=0.1$ and 0.3 , respectively. It may interprets that gallium content in the compound may play 
Table 1 Comparison of particle size obtained by DLS and XRD

\begin{tabular}{llll}
\hline Compound & $\begin{array}{l}\text { Particle size } \\
D(\mathrm{~nm}) \\
\text { XRD }\end{array}$ & $\begin{array}{l}\text { Particle size } \\
D(\mathrm{~nm})\end{array}$ & $\begin{array}{l}\text { FWHM } \\
\text { DLS }\end{array}$ \\
& 123 & 124 & \\
\hline $\mathrm{CuInSe}_{2}$ & 64 & 65 & 0.2309 \\
$\mathrm{CuIn}_{0.9} \mathrm{Ga}_{0.1} \mathrm{Se}_{2}$ & 48 & 50 & 0.2460 \\
$\mathrm{CuIn}_{0.7} \mathrm{Ga}_{0.3} \mathrm{Se}_{2}$ & & & 0.5904
\end{tabular}
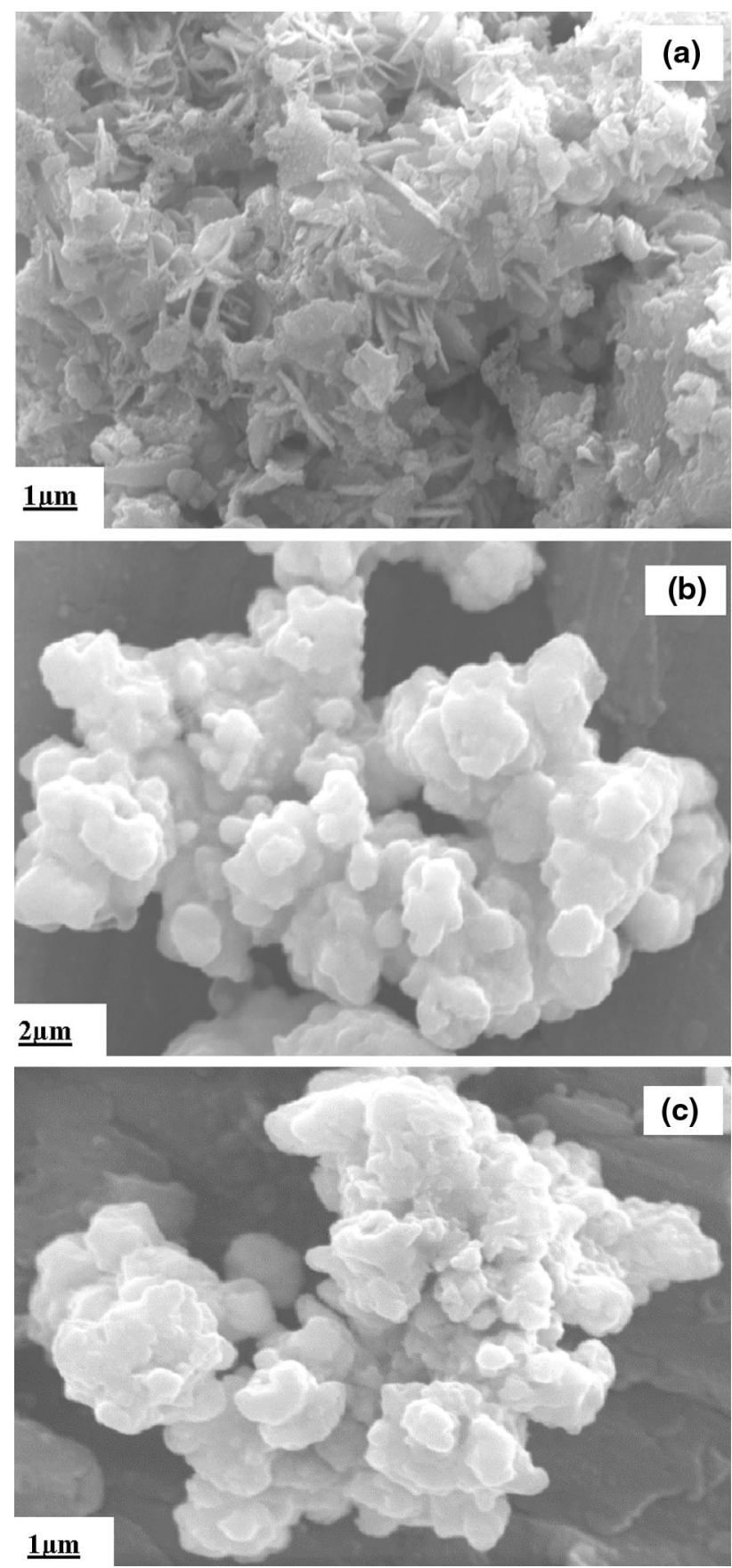

Fig. 4 Scanning electron microscopy for a CuInSe $2, \mathbf{b} \mathrm{Cu}\left(\mathrm{In}_{0.9} \mathrm{Ga}_{0.1}\right)$ $\mathrm{Se}_{2}$, and c $\mathrm{Cu}\left(\mathrm{In}_{0.7} \mathrm{Ga}_{0.3}\right) \mathrm{Se}_{2}$ nanostructure

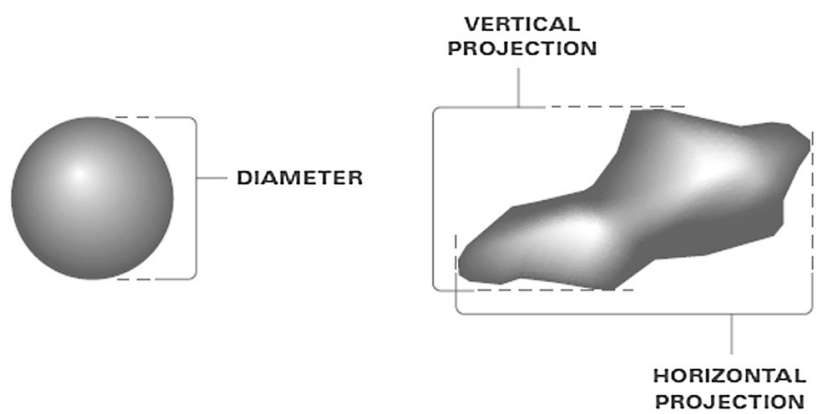

Fig. 5 Size determination for non-spherical particles can be described using multiple length and width measures (horizontal and vertical projections)

an important role in the growth of nanoparticles in particular direction.

Particle size of as-grown nanostructure is measured by dynamic light scattering (DLS) at room temperature. Size determination by a light scattering device for spherical particle can be described using diameter, because every dimension of spherical particle is identical. Figure 5 shows, in case of non-spherical particles, to provide greater accuracy, that the size evaluation can be done using multiple length and width measures (horizontal and vertical projections). A light-scattering device makes an average for various dimensions, as the particles flow randomly through the light beam, producing a distribution of sizes from the smallest to the largest dimensions.

In our work, before taking DLS measurement, sample is filtered by micro-filter kit of $0.45 \mu \mathrm{m}$ pore size to remove dust particles. Sonication is also done to remove agglomeration, which effects DLS measurements. To make the measurement, the as-grown product is dispersed in methanol. Before taking particle size measurement, we first evaluate the correlation function. Figure $6 \mathrm{a}-\mathrm{c}$ shows the size distribution curve of as-grown particles. The average diameters of synthesized nanostructures are evaluated as 124, 65, and $50 \mathrm{~nm}$ for $\mathrm{CuInSe} 2, \mathrm{Cu}\left(\mathrm{In}_{0.9} \mathrm{Ga}_{0.1}\right) \mathrm{Se}_{2}$, and $\mathrm{Cu}\left(\mathrm{In}_{0.7} \mathrm{Ga}_{0.3}\right) \mathrm{Se}_{2}$, respectively, which demonstrate that grain size and grain boundaries of CIGS nanostructure decrease with increase in Ga content. It is found that the estimated particle size by XRD and DLS differs; it still interprets agglomeration formation in as-grown nanostructures. Table 1 enlists the comparison of particle size, calculating by XRD and measuring through DLS.

Figure 7 shows the absorption spectra of CIS and CIGS with varying gallium content. The absorption spectra of CIGS are recorded in the range of $380-1100 \mathrm{~nm}$ using methanol as reference. The sharp absorption edges at the fundamental absorption region shift toward lower wavelength by increasing gallium content from $x=0,0.1$, and 0.3. Simultaneously, magnitude of absorption near the fundamental absorption edge decreases because of 

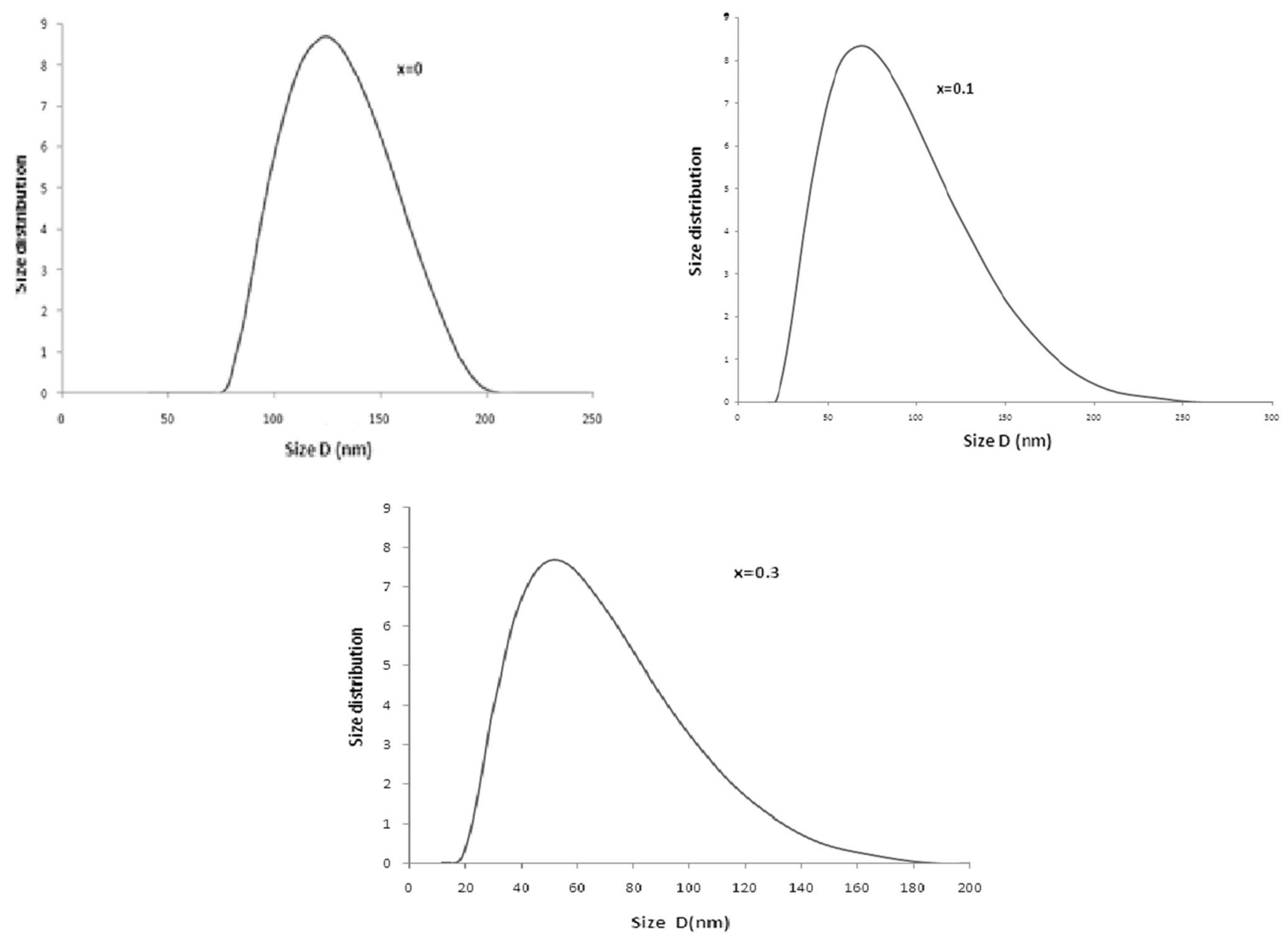

Fig. 6 Size distribution curve of $\mathrm{CuInSe}_{2}(x=0), \mathrm{Cu}\left(\mathrm{In}_{0.9} \mathrm{Ga}_{0.1}\right) \mathrm{Se}_{2},(x=0.1)$ and $\mathrm{Cu}\left(\mathrm{In}_{0.7} \mathrm{Ga}_{0.3}\right) \mathrm{Se}_{2}(x=0.3)$ nanostructure

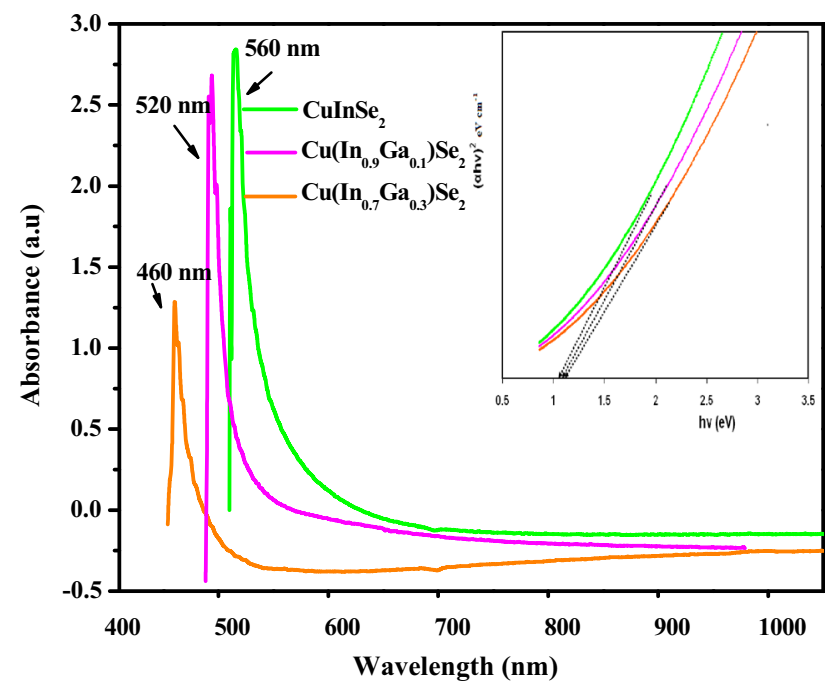

Fig. 7 Absorption spectrum of $\mathrm{CuInSe}_{2}, \mathrm{Cu}\left(\mathrm{In}_{0.9} \mathrm{Ga}_{0.1}\right) \mathrm{Se}_{2}$, and $\mathrm{Cu}\left(\mathrm{In}_{0.7} \mathrm{Ga}_{0.3}\right) \mathrm{Se}_{2}$ prepared in ethanolamine

decreasing grain sizes due to an increase of Ga content and more grain boundaries, which scattered incident light. However, large onset of all three nanostructures reveals wide range of particle size distribution. For $x=0,0.1$, and 0.3 , the calculated optical band gaps are 1.02, 1.10, and $1.20 \mathrm{eV}$, respectively (shown in the inset of Fig. 7). In short, the CIGS samples show bowing in band gaps with variation of $\mathrm{Ga}$ composition. The bandgap evaluated of $\mathrm{CuIn}_{1-x} \mathrm{Ga}_{x} \mathrm{Se}_{2}$ compound nearly matches with solar spectrum and can be used as an absorber layer in thin-film solar cells.

This technique provides information about the chemical bonding in a material. It is used to identify the elemental constituents of a material. Figure 8 shows the Fourier transform infrared (FTIR) spectra of as prepared singlephase copper indium gallium diselenide (CIGS) nanoparticles. Before FTIR measurement, the sample is milled with $\mathrm{KBr}$ to form a fine powder. The spectra range is taken from 400 to $4000 \mathrm{~cm}^{-1}$ assign vibration spectra of the compound. Before FTIR analysis, the samples are rinsed with methanol and distill water several times and then dried at $60{ }^{\circ} \mathrm{C}$ for $1 \mathrm{~h}$.

Figure 8 shows the FTIR spectra of single-phase CIS $(x=0)$ and CIGS $(x=0.1)$ compound. From Fig. 8a, the 

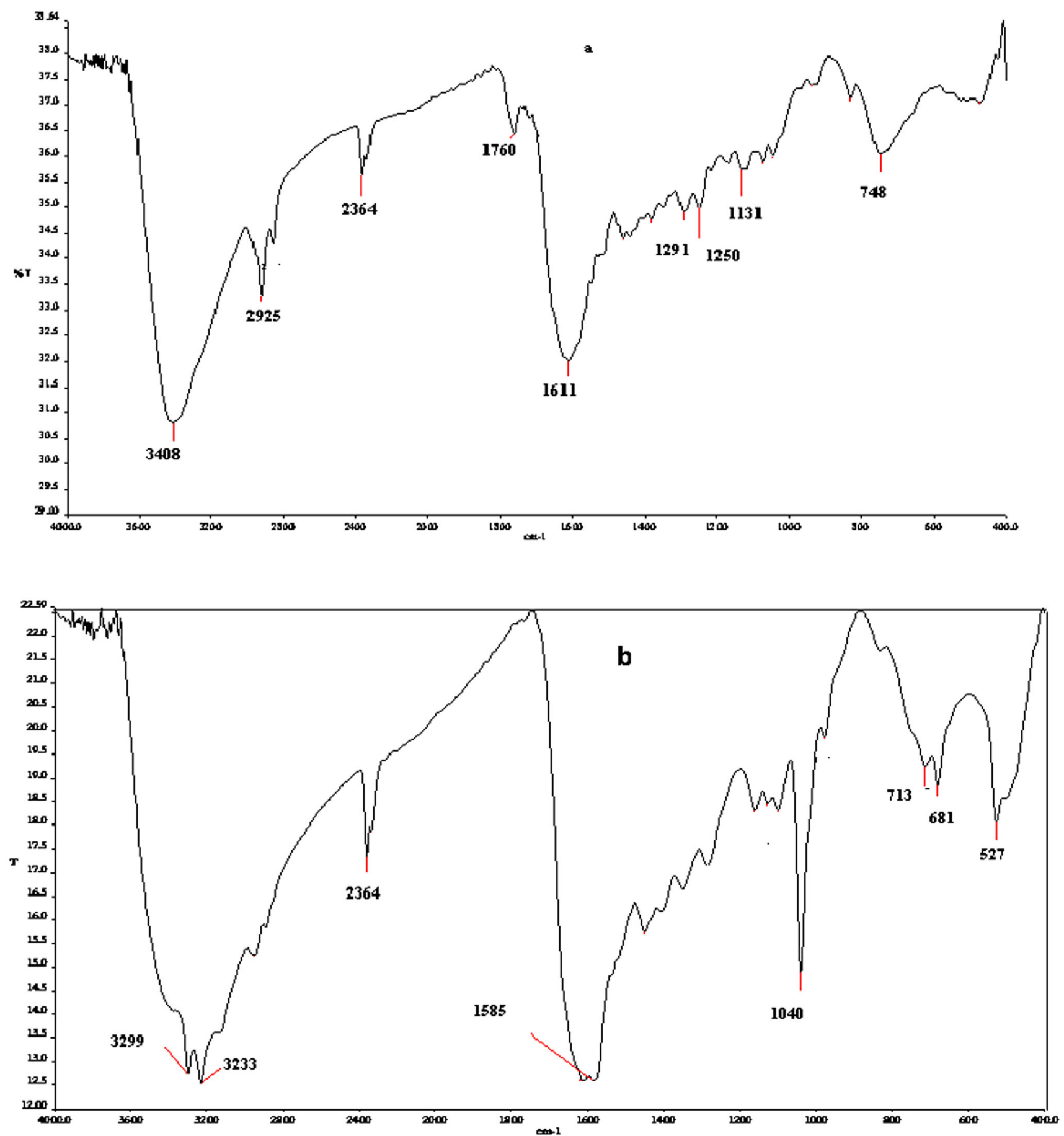

Fig. 8 FTIR spectra of single-phase CIS $(x=0)$ and CIGS $(x=0.1)$ compound

broad peak is observed at $3408 \mathrm{~cm}^{-1}$ assigned to $-\mathrm{OH}$ stretching intermolecular hydrogen bonds due to the small quantity of $\mathrm{H}_{2} \mathrm{O}$ or moisture on the sample. The vibration peak at $2925 \mathrm{~cm}^{-1}$ assigns to $\mathrm{O}-\mathrm{H}$ stretch due to rinsing sample with methanol several times. The weak and sharp peaks at $2364 \mathrm{~cm}^{-1}$ assign to $\mathrm{C}-\mathrm{H}$ stretch confirms formation of $[\mathrm{Cu}(\mathrm{en})]^{+}$in the compound. $\mathrm{N}-\mathrm{H}$ stretching vibration peak is observed at $1611 \mathrm{~cm}^{-1}$ due to preparation of $\mathrm{CuInSe}_{2}$ in the ethylenediamine. Broad peak observed at $748 \mathrm{~cm}^{-1}$, recognized as $\mathrm{C}-\mathrm{H}$ bond (disubstituted), reveals chelate formation in CIS compound. As shown in Fig. 8b, the two sharp peaks at 3299 and $3233 \mathrm{~cm}^{-1}$ assigned $\mathrm{N}-\mathrm{H}$ stretch due to ethanolamine used for synthesis. Again, vibration broad peak at $1585 \mathrm{~cm}^{-1}$ is of $\mathrm{N}-\mathrm{H}$ bond. Sharp 
peak at $1040 \mathrm{~cm}^{-1}$ is assigned to $\mathrm{C}-\mathrm{N}$ stretch that shows formation of chelate complex in ethanolamine. Weak and broad peaks at 713 and $681 \mathrm{~cm}^{-1}$ are $\mathrm{C}-\mathrm{Cl}$ stretch. Again broad peak at $527 \mathrm{~cm}^{-1} \mathrm{C}-\mathrm{Br}$ stretch is due to IR spectra obtained with $\mathrm{KBr}$ and $\mathrm{NaCl}$.

\section{Conclusion}

Single-phase CIGS nanostructures are successfully synthesized by taking $x=0.1$ with the starting precursors of dihydrate cupric chloride, Indium (III) chloride, Gallium (III) chloride, and Se powder using ethanolamine as a solvent. The chemical bonding investigated by FTIR of single phase that was obtained at $x=0$ and 0.1 samples gives the presence of bonds and used to identify the elemental constituent of a material.

Open Access This article is distributed under the terms of the Creative Commons Attribution 4.0 International License (http:// creativecommons.org/licenses/by/4.0/), which permits unrestricted use, distribution, and reproduction in any medium, provided you give appropriate credit to the original author(s) and the source, provide a link to the Creative Commons license, and indicate if changes were made.

\section{References}

Alberts V (2004) Band gap engineering in polycrystalline $\mathrm{Cu}(\mathrm{In}, \mathrm{Ga})(\mathrm{Se}, \mathrm{S})_{2}$ chalcopyrite thin films. Mater Sci Eng B 107:139-147

Alberts V (2009) Band gap optimization in $\mathrm{Cu}\left(\mathrm{In}_{1-x} \mathrm{Ga}_{x}\right)\left(\mathrm{Se}_{1-\mathrm{y}} \mathrm{S}_{\mathrm{y}}\right)_{2}$ by controlled $\mathrm{Ga}$ and $\mathrm{S}$ incorporation during reaction of $\mathrm{Cu}-(\mathrm{In}, \mathrm{Ga})$ intermetallics in $\mathrm{H}_{2} \mathrm{Se}$ and $\mathrm{H}_{2} \mathrm{~S}$. Thin Solid Films 517:2115-2120

Bensebaa F, Durand C, Aouadou A, Scoles L, Du X, Wang D, Page YL (2010) A new green synthesis method of $\mathrm{CuInS}_{2}$ and $\mathrm{CuInSe}_{2}$ nanoparticles and their integration into thin films. J Nanopart Res 12:1248-1252
Bremeud D, Rudmann D, Kalein M, Ernits K, Bilger G, Dobeli M, Zogg H, Tiwari AN (2007) Flexible $\mathrm{Cu}(\mathrm{In}, \mathrm{Ga}) \mathrm{Se}_{2}$ on $\mathrm{Al}$ foils and the effects of $\mathrm{Al}$ during chemical bath deposition. Thin Solid Films 515:5857-5861

Caballero R, Kaufmann CA, Eisenbarth T, Canclea M, Hesse R, Unold T, Eicke A, Klenk R, Schock HW (2009) The influence of $\mathrm{Na}$ on low temperature growth of CIGS thin film solar cells on polyimide substrates. Thin Solid Films 517:2187-2190

Jackson P, Hariskos D, Lotter E, Paetel S, Wuerz R, Menner R (2011) New world record efficiency for $\mathrm{Cu}(\mathrm{In}, \mathrm{Ga}) \mathrm{Se}_{2}$ thin-film solar cells beyond $20 \%$. Prog Photovol Res Appl 19:894-897

Juhaiman LA, Scoles L, Kingston D, Patarachao B, Wang D, Bensebaa F (2010) Green synthesis of tunable $\mathrm{Cu}\left(\mathrm{In}_{1-x} \mathrm{Ga}_{x}\right) \mathrm{Se}_{2}$ nanoparticles using non organic solvents. Green Chem 12:1248-1252

Kim KH, Chun YG, Yoon KH, Park BO (2005) Synthesis of $\mathrm{CuInGaSe}_{2}$ nanoparticles by low temperature colloidal route. J Mech Sci Technol 19:2085-2090

Panthani MG, Akhavan V, Goodfellow B, Schmidtke JP, Dunn L, Dodabalapur A, Barbara PF, Gorgel BA (2008) Synthesis of $\mathrm{CuInS}_{2}, \mathrm{CuInSe} 2$, and $\mathrm{Cu}\left(\mathrm{In}_{x} \mathrm{Ga}_{1-x}\right) \mathrm{Se}_{2}$ (CIGS) nanocrystal "Inks" for printable photovoltaics. J Am Chem Soc 130:16770-16777

Rehani B, Ray JR, Panchal CJ, Master H, Desai RR, Patel PB (2013) Mechanochemically synthesized CIGS nanocrystalline powder for solar cell applications. J Nano Electron Phys 5:02007-02010

Repins I, Contreras MJ, Romero EB, DeHart C, Scarf J, Perkins CJ, To B, Noufi R, Scharf J (2008) $19.9 \%$ efficient $\mathrm{ZnO} / \mathrm{CdS} /$ $\mathrm{CuInGaSe}_{2}$ solar cell with $81.2 \%$ fill factor. Prog Photovolt Res Appl 16:235-239

Souilah M, Rocquefelte X, Lafond A, Guillot-Deudon C, Morniroli JP, Kessler J (2009) Crystal structure re-investigation in wide band gap CIGSe compounds. Thin Solid Films 517:2145-2148

Tang J, Hinds S, Kelley SO, Sargent EH (2008) Synthesis of colloidal $\mathrm{CuGaSe}_{2}, \mathrm{CuInSe} \mathrm{S}_{2}$, and $\mathrm{Cu}(\mathrm{InGa}) \mathrm{Se}_{2}$ nanoparticles. Chem Mater 22:6906-6910

Vidhya B, Velumani S, Asomoza R (2011) Effect of milling time and heat treatment on the composition of CuIn $0.75 \mathrm{Ga} 0.25 \mathrm{Se}_{2}$ nanoparticle precursors and films. J Nanopart Res 13:3033-3042

Zhang L, He Q, Jiang WL, Liu FF, Li CJ, Sun Y (2009) Effects of substrate temperature on the structural and electrical properties of $\mathrm{Cu}(\mathrm{In}, \mathrm{Ga}) \mathrm{Se}_{2}$ thin films. Sol Energy Mater Solar Cells 93:114-118 